\title{
Finanzas en familia y Coronavirus (COVID-19)
}

Por: Griselda Aguilar Pacas

Máster en Dirección de Empresas, Docente e Investigadora del Departamento de Contabilidad y Finanzas de la Universidad Centroamericana José Simeón Cañas (UCA)

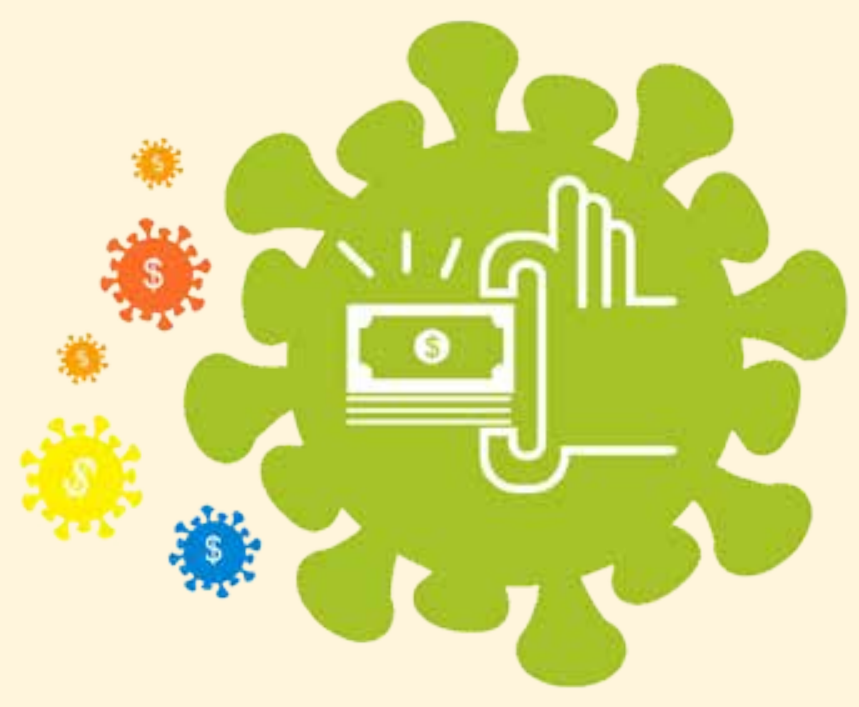

debes cocinar solo por cocinar, sino ver qué alimentos tienes, reinventar recetas, contar el número de personas en casa y las porciones que debes cocinar. Además, es recomendable ejecutar actividades en pro de aprender nuevas habilidades, leer, hacer actividad física, ocupar el tiempo para no exceder el consumo de alimentos, ya que esto afectará tu salud, presupuesto y tu mente.

\section{b) Medicamentos recetados.}

c) Transporte para trasladar las compras de alimentación y medicamentos.

d) Procura guardar un fondo de emergencia (ahorro): hoy más que nunca queda demostrado que es vital tenerlo. Finalmente, intenta no endeudarte y levanta el teléfono para explicar tu situación, sin pena, a todos los que les adeudas (no lo des por sentado); ellos te entenderán o buscarán una forma de ayudarte.

ii. Familias con ingresos normales, sin ninguna modificación: debes actuar con normalidad con todas tus obligaciones y crear el fondo de emergencia (dejar dinero en efectivo guardado) y, si ya lo tenías, fortalecerlo. Es necesario realizar tus pagos para mantener viva la economía y cuidar de tu salud financiera (porque recuerda que los pagos que no efectúes hoy, mañana los deberás enfrentar).

Así que preparémonos para lo peor, para esperar lo mejor siempre. manifiestan que esta partida se ha incrementado porque no estás racionando las porciones. No 